Z. Klin. Chem. Klin. Biochem.

13. Jg. 1975 , S. $305-310$

\title{
Bound and Free Light Chains in Subacute Sclerosing Panencephalitis and Multiple Sclerosis Serum and Cerebrospinal Fluid
}

\author{
By F. Bollengier, A. Lowenthal and W. Henrotin ${ }^{1}$ ) \\ Laboratorium Fysiopathologie van het Zenuwstelsel, Vrije Universiteit Brussel, Brussels
}

(Eingegangen am 22. November 1974/21. Februar 1975)

Summary: The kappa-lambda light chain ratios, the presence of free light chains and the double ring formation, with antikappa and antilambda serum, in single radial immunodiffusion were investigated in serum and cerebróspinal fluid of patients with subacute sclerosing panencephalitis.

Cerebrospinal fluid samples of several multiple sclerosis cases were considered simultaneously. The results obtained suggest special immunoglobulin synthesis in both diseases.

\section{Gebundene und freie leichte Ketten in Serum und Liquor cerebrospinalis bei Subakuter Sklerosierender Panencepha-} litis und Multipler Sklerose

Zusammenfassung: In Serum und Liquor cerebrospinalis von Patienten mit subakuter sklerosierender Panencephalitis wurden die Verhältnisse von leichten Kappa- zu leichten Lambda-Ketten und die Doppelring-Bildung mit anti-Kappaund anti-Lambda-Serum in der einfachen radialen Immundiffusion untersucht.

Liquorproben zahlreicher Fälle von Multipler Sklerose wurden ebenfalls untersucht. Die Ergebnisse sprechen für eine spezielle Imunnglobulinsynthese bei beiden Erkrankungen.

When examined by agar gel electrophoresis, the gammaglobulins of the cerebrospinal fluid in multiple sclerosis appear in the form of two or more discrete bands (1), also called oligoclonal immunoglobulins.

Since the first description of this particular phenomenon it is considered as the best biological diagnosis of multiple sclerosis; however it is not specific for multiple sclerosis, and can be found in other diseases.

Several authors studied the characteristics of the immunoglobulins in multiple sclerosis.

According to Link (2), the ratio of the kappa-lambda light chains is increased in the cerebrospinal fluid of multiple sclerosis patients, whereas in serum of the same patients the values are mostly identical to those of the controls.

More recently, Iwashita (3) reported the double ring formation in single radial immunodiffusion for light chains of type kappa, in unconcentrated multiple sclerosis and subacute sclerosing panencephalitis-cerebrospinal fluid.

The purpose of this paper is to investigate those particular features in 12 cases of subacute sclerosing panencephalitis, a disease which is characterized by the

1) W. Henrotin: Hoechst Belgium - Behringwerke Department appearance of oligoclonal gamma-globulins, both in the serum and cerebrospinal fluid. In parallel we studied 9 cases of multiple sclerosis, in order to add possibly new findings or to confirm earlier ones.

Furthermore, the serum and cerebrospinal fluid of subacute sclerosing panencephalitis and multiple sclerosis patients were screened for the presence of free light chains.

\section{Material and Methods}

The diagnosis of subacute sclerosing panencephalitis was established on the following criteria: the clinical course of the disease, electroencephalogram, examination of the serum and cerebrospinal fluid by agar gel electrophoresis, titration of the mcasles antibodies in serum and cerebrospinal fluid and eventually brain biopsy. Only those cases which answered positively to the four first criteria were accepted as certain.

For multiple sclerosis the criteria were:

clinical multifocal lesions of the central nervous system, the typical clinical evolution of the discase and examination of the cerebrospinal fluid by agar $\mathrm{gcl}$ electrophoresis.

In all cases the gamma-globulins in the cerebrospinal fluid were increased and fractionated.

Control sera were assayed directly after centrifugation, and then stored frozen. All pathological scrum samples had been stored frozen at least several months before use.

Cerebrospinal fluid samples, obtained by lumbar puncture, were stored frozen for siveral months, except the controls. which were used immediatcly. All cerebrospinal fluid samples were concentrated twenty times when measured by single 

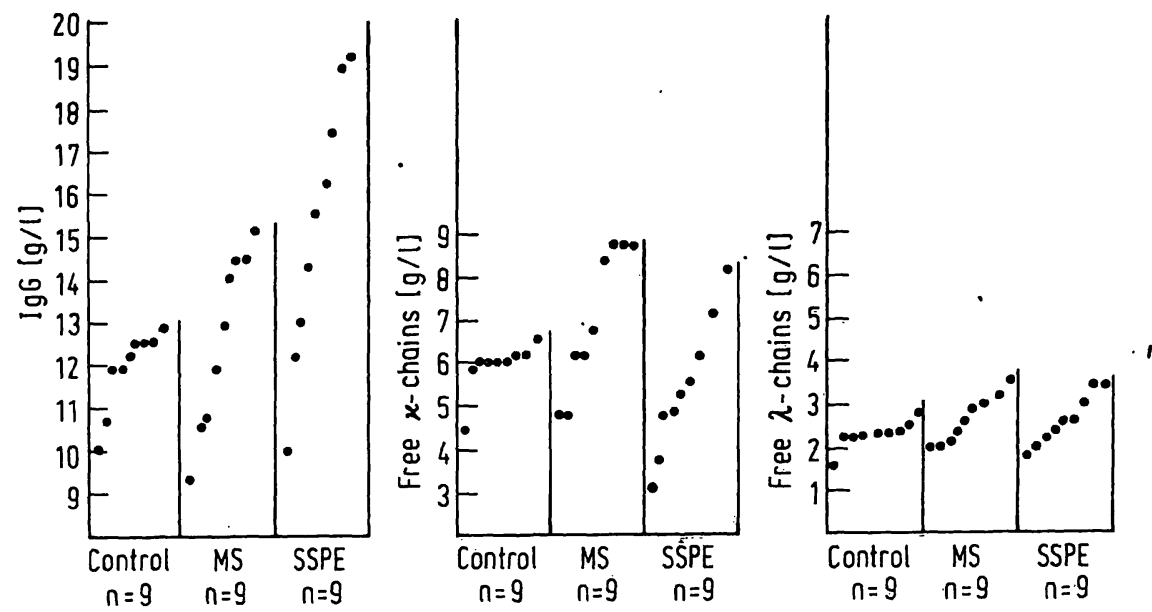

Fig. 1. IgG, kappa and lambda levels in serum from controls, multiple sclerosis and subacute sclerosing panencephalitis cases.

radial immunodiffusion (4) against total and free light chain antiscra ${ }^{1}$ ).

The IgG content was measured by single radial immunodiffusion, using Tripartigen ${ }^{2}$ ) platcs for the serum, and LC Partigen ${ }^{3}$ ) plates for the cerebrospinal fluid.

For the preparation of the agar plates with incorporated light chain antiserum, the following procedure was used:

$2 \%$ agar (Difco Noble) was prepared in barbital buffer pH 8.6 $(\mu 0.05)$ and made ù to $4 \%$ in concentration of the particular antibodies at $56^{\circ} \mathrm{C}$ and $5 \mathrm{ml}$ of each solution was poured in an empty partigen box.

Wells were punched into the gel and filled with $5 \mu$ l serum or cerebrospinal fluid.

Diffusion at room temperature was allowed for 50 hours. For scrum and cerebrospinal fluid samples, devcloped against total light chain antiscrum, the precipitation lines appeared vcry clearly, and were read after careful washings with 0.01 $\mathrm{mol} / 1$ phosphate $0.15 \mathrm{~mol} / 1 \mathrm{NaCl}$ buffer $\mathrm{pH} 7.4$.

When developed against free light chain antiserum, the agar gel plates were either, first washed several times with distilled water, covered with a fresh solution of $197 \mathrm{mg}$ DOPA in $0.1 \mathrm{~mol} / \mathrm{l}$ phosphate buffer $\mathrm{pH} 7.2$ (5), incubated overnight and finally rewashed with distilled water, or washed with phosphate buffered saline, covered with a $4 \%$ aqueous tannic acid solution for 30 minutes, and washed with distilled water for 1 hour. The diameters of the rings were measured for each sample and the kappa, lambda concentrations calculated from a standard curve, established with several dilutions of reference kappa and lambda Bence Jones proteins.

\section{Results}

Table 1 and 2 give the mean values \pm SEM and the significant differences between controls and pathological cases on the one hand, and on the other hand, between subácute sclerosing panencephalitis and multiple sclerosis cases.

1) Goat serum anti Bence Jones typc kappa TNN/05 Behringwerke AG - Marburg/Lahn

Goat serum anti Bence Jones type lambda TNO/05 Behringwerke AG - Marburg/Lahn

Rabbit serum anti Bence Jones type kappa TNL/05 -

Behringwerke AG - Marburg/Lahn

Rabbit serum anti Bence Jones type lambda TNM/05 Behringwerke AG - Marburg/Lahn

2) Tri-Partigen - IgG - TDS/03 - Behringwerke AG Marburg/Lahn

3) LC Partigen - IgG - TCR/03 - Behringwerke AG Marburg/Lahn
In serum the total IgG content, when compared to the controls, was increased in the pathological cases, but more significantly in subacute sclerosing panencephalitis than in multiple sclerosis (fig. 1).

Tab. 1. Mean values \pm SEM and the significant differences between control and pathological sera for $p=0.05$.

\begin{tabular}{|c|c|c|c|}
\hline$g / 1$ & Control & $\begin{array}{l}\text { Multiple } \\
\text { sclerosis }\end{array}$ & $\begin{array}{l}\text { Subacute } \\
\text { sclerosing } \\
\text { panence- } \\
\text { phalitis }\end{array}$ \\
\hline \multicolumn{4}{|l|}{ IgG } \\
\hline & $11.90 \pm 0.95$ & $12.58 \pm 2.06$ & $15.23 \pm 3.17 *$ \\
\hline $\begin{array}{l}M \pm S E M \\
\text { Lambda total }\end{array}$ & $5,98 \pm 0.60$ & $7.08 \pm 1.68^{*}$ & $5.47 \pm 1.61$ \\
\hline $\begin{array}{l}\mathrm{M} \pm \mathrm{SEM} \\
\text { Kappa/lambda }\end{array}$ & $a^{2,34 \pm 0.31}$ & $2.61 \pm 0.54$ & $2.62 \pm 0.56$ \\
\hline $\mathrm{M} \pm \mathrm{SEM}$ & $2.57 \pm 0.12$ & $2.74 \pm 0.57 * *$ & $2.10 \pm 0.31 * / * *$ \\
\hline
\end{tabular}

* pathological values differ significantly from controls for p 0.05

** multiple sclerosis values differ significantly from subacute sclerosing panencephalitis values for $\mathrm{p} 0.05$

Tab. 2. Mean values \pm SEM and significant differences between control and pathological cerebrospinal fluid for $p=0.05$

\begin{tabular}{|c|c|c|c|}
\hline $\mathrm{mg} / \mathrm{l}$ & Control & $\begin{array}{l}\text { Multiple } \\
\text { sclerosis }\end{array}$ & $\begin{array}{l}\text { Subacute } \\
\text { sclerosing } \\
\text { panence- } \\
\text { phalitis }\end{array}$ \\
\hline \multicolumn{4}{|l|}{ IgG } \\
\hline $\begin{array}{l}\mathrm{M} \pm \mathrm{SEM} \\
\text { Kappa total }\end{array}$ & $19.5 \pm 11.3$ & $49.4 \pm 31.6 * / * *$ & $112.4 \pm 40.8 * / * *$ \\
\hline $\begin{array}{l}M \pm S E M \\
\text { Lambda total }\end{array}$ & $8.7 \pm 4.7$ & $25.4 \pm 14.0^{*}$ & $28.0 \pm 13.2^{*}$ \\
\hline $\begin{array}{l}\mathrm{M} \pm \mathrm{SEM} \\
\text { Kappa/lambda }\end{array}$ & $3.6 \pm 1.7$ & $7.4 \pm 3.4^{*}$ & $14.5 \pm 10.0^{*}$ \\
\hline $\mathrm{M} \pm \mathrm{SEM}$ & $2.4 \pm 0.2$ & $4.3 \pm 3.6$ & $2.9 \pm 1.9$ \\
\hline
\end{tabular}

* pathological values differ significantly from controls for p 0.05

** multiple sclerosis values differ significantly from subacute sclerosing panencephalitis values for $\mathrm{p} 0.05$ 
Consequently, the kappa-lambda ratio was increased in multiple sclerosis and slightly decreased in subacute sclerosing panencephalitis with regard to the controls (fig. 2).

When screened for the presence of free chains with the Ouchterlony immunodiffusion technique, none were detected, either in the control, or in pathological samples.

In cerebrospinal fluid the IgG values were increased both in multiple sclerosis and subacute sclerosing panencephalitis, but to a more important amount in subacute sclerosing panencephalitis.

The values of total kappa and lambda chain are considerably increased in both diseases, when compared to those of the controls. But the lambda chain concen-

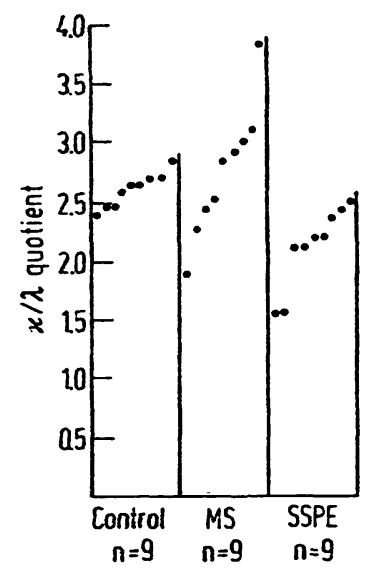

Fig. 2. Kappa/lambda ratio in serum from controls, multiple sclerosis and subacute sclerosing panencephalitis tration is more significantly increased in subacute sclerosing panencephalitis than in multiple sclerosis (fig. 3).

The kappa-lambda ratio is increased up to 11 for multiple sclerosis patients, and up to 6.5 for subacute sclerosing panencephalitis patients. The control values of kappa/lambda in cerebrospinal fluid are about 2.4 (fig. 4).

Double ring formation with total kappa antiserum was noticed in 8 out of 9 multiple sclerosis cases, and 11 out of 12 subacute sclerosing panencephalitis cases (fig. 5,6 ).

With total lambda antiserum 6 multiple sclerosis and 4 subacute sclerosing panencephalitis cases displayed

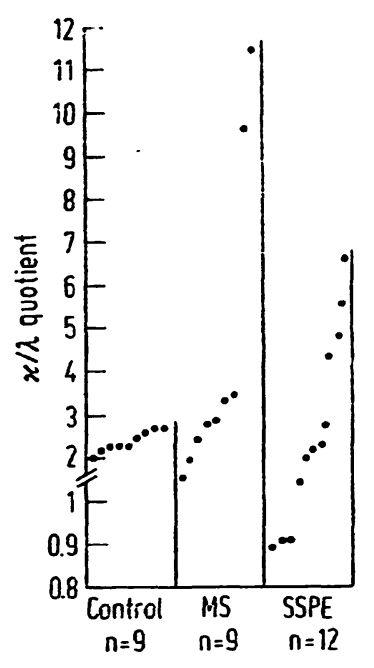

Fig. 4. Kappa/lambda ratio in cerebrospinal fluid from controls, multiple sclerosis and subacute sclerosing panencephalitis.
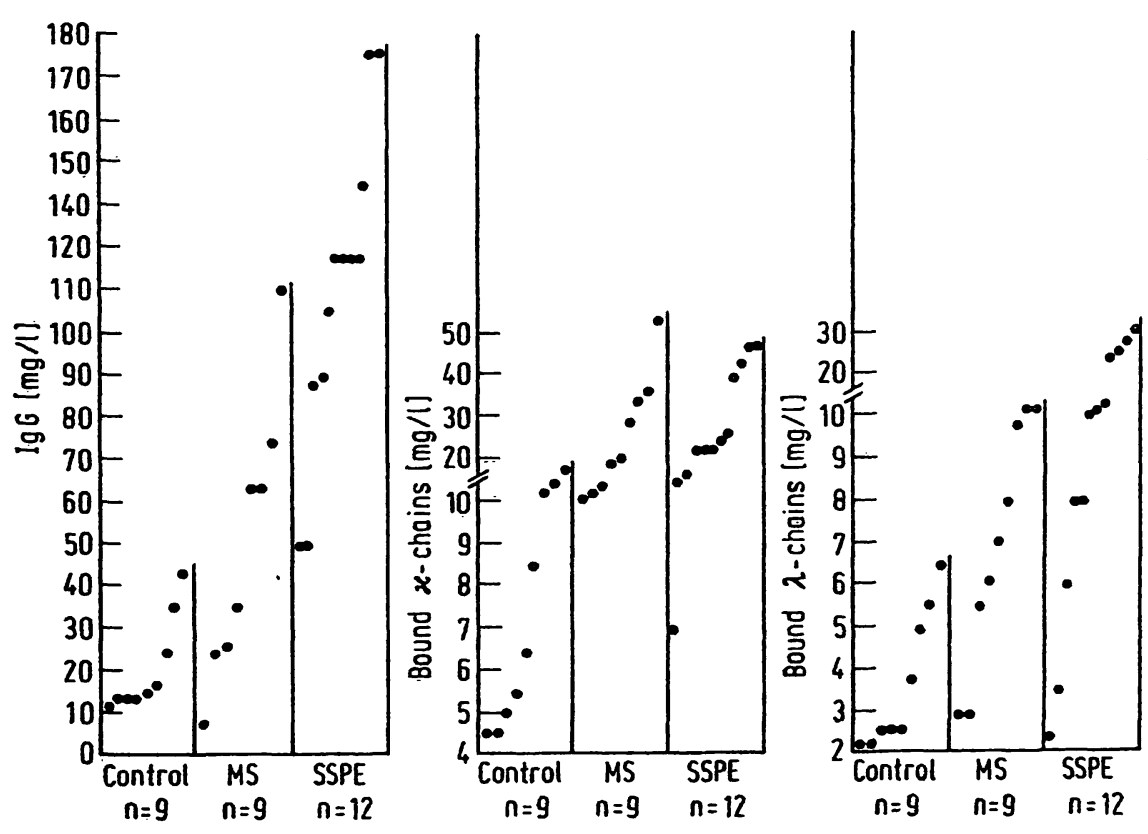

Fig. 3. IgG, kappa and lambda levels in cerebrospinal fluid from controls, multiple sclerosis and subacute sclerosing panencephalitis cases. 


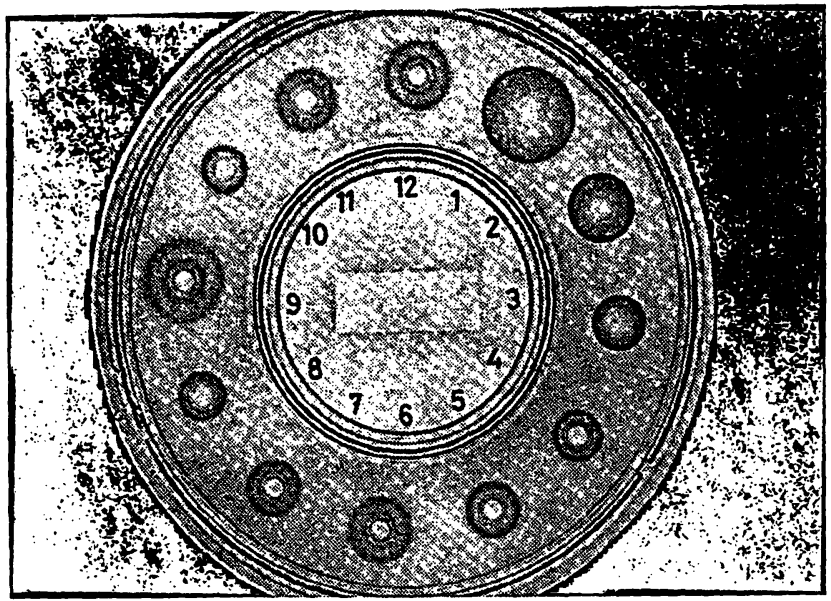

Fig. 5. Radial immunodiffusion of concentrated multiple sclerosis cerebrospinal fluid samples; kappa chains.

1) Bence Jones kappa: $620 \mathrm{mg} / \mathrm{l}$

2) Bence Jones kappa: $310 \mathrm{mg} / \mathrm{l}$

3) Bence Jones kappa: $160 \mathrm{mg} / 1$

4)-12) multiple sclerosis cerebrospinal fluid

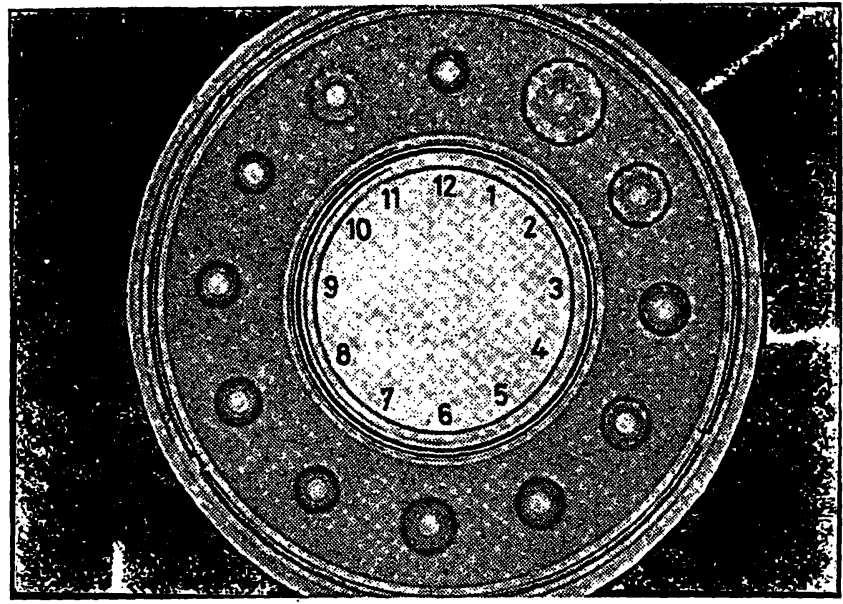

Fig. 7. Radial immunodiffusion of concentrated multiple sclerosis cerebrospinal fluid; lambda chains.

1) Bence Jones lambda: $31.0 \mathrm{mg} / \mathrm{l}$

2) Bence Jones lambda: $160 \mathrm{mg} / \mathrm{l}$

3) Bence Jones lambda: $80 \mathrm{mg} / 1$

4)-12) multiple sclerosis cerebrospinal fluid

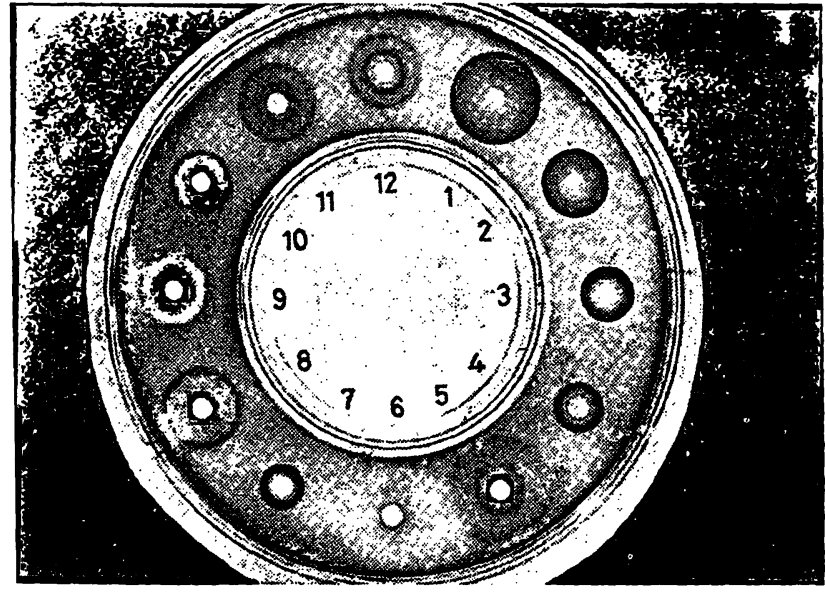

Fig. 6. Radial immunodiffusion of concentrated subacute sclerosing panencephalitis cerebrospinal fluid; kappa chains.

1) Bence Jones kappa: $620 \mathrm{mg} / 1$

2) Bence Jones kappa: $310 \mathrm{mg} / \mathrm{l}$

3) Bence Jones kappa: $160 \mathrm{mg} / \mathrm{l}$

7)-12) subacute sclerosing panencephalitis cerebrospinal fluid

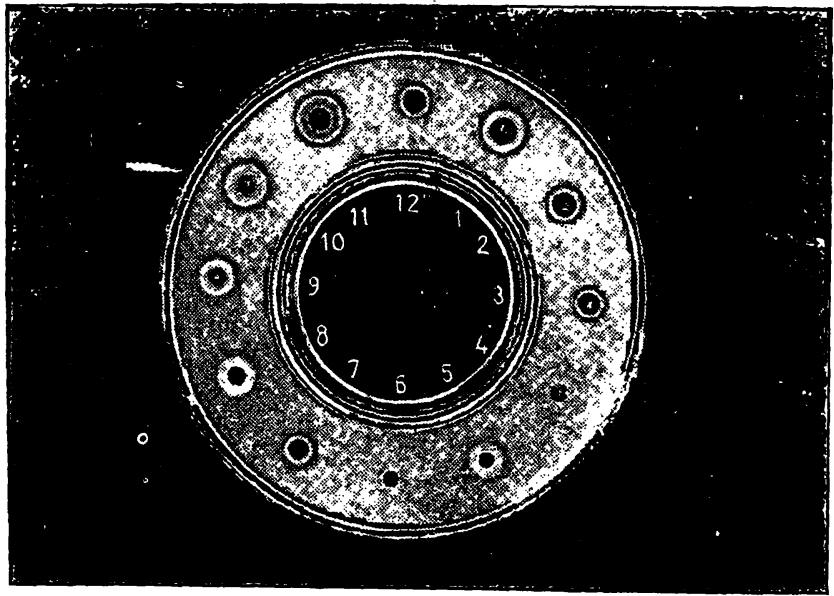

Fig. 8. Radial immunodiffusion of concentrated subacute sclerosing panencephalitis cerebrospinal fluid; free kappa chains.

1) Bence Jones kappa: $80 \mathrm{mg} / 1$

2) Bence Jones kappa: $40 \mathrm{mg} / 1$

3) Bence Jones kappa: $20 \mathrm{mg} / 1$

7)-12) subacute sclerosing panencephalitis cerebrospinal fluid

Z. Klin. Chem. Klin. Biochem. / 13. Jahrg. 1975 / Heft 7 
double rings, but they did not appear so clearly as with total kappa antiserum (fig. 7).

Cerebrospinal fluid samples of controls were negative when developed against free light chains antiserum. But 8 multiple sclerosis -cerebrospinal fluid had free kappa chains and 3 of them free lambda chains; 11 out of 12 subacute sclerosing panencephalitis cases had both free kappa and lambda chains (fig. 8, 9).

The kappa-lambda ratio of the free chains in subacute sclerosing panencephalitis was below 2 for all of them.
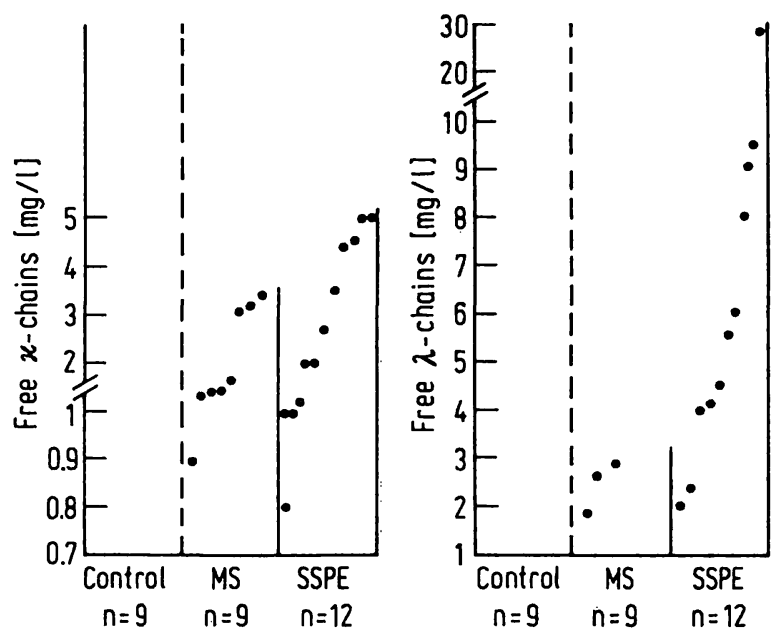

Fig. 9. Free kappa and lambda levels in cerebrospinal fluid from multiple sclerosis and subacute sclerosing panencephalitis cases.

\section{Discussion}

1. The quantitative distribution of IgG, kappa and lambda chains, is much more even in control serum and cerebrospinal fluid, than in the pathological samples where the values are widely spread.

In serum the multiple sclerosis cases we screened had generally higher kappa-lambda ratios than the controls, a fact which does not entirely correspond with Link's results. According to Link (2) the kappalambda ratio in multiple sclerosis serum is almost identical to the controls.

On the contrary, all subacute sclerosing panencephalitis cases, we studied, had lower rates than controls.

In multiple sclerosis-cerebrospinal fluid, the total kappa chains were increased, whereas in subacute sclerosing panencephalitis-cerebrospinal fluid the lambda chain increase dominated.

One has the impression that in both diseases there is a synthesis of particular immunoglobulins: predominantly kappa immunoglobulins for multiple sclerosis and lambda immunoglobulins for subacute sclerosing panencephalitis.
The presence of free light chains in multiple sclerosis and subacute sclerosing panencephalitis-cerebrospinal fluid is a fact difficult to explain. Do those free chains originate from a natural proteolysis of the immunoglobulins, or are they a result of a defective synthesis, are questions still unanswered.

2. According to Lietze (6) and Mulder (7-8), multiple precipitation, noticed in pathological samples in single radial immunodiffusion is either due to the blocking of antigenic determinants by other bound proteins, or due to the lack of antigenic determinants in the individual immunoglobulins.

In recent studies on myeloma proteins, Mulder suggests that double precipitation is caused by the deficiency of certain antibody determinants. According to this, we can assume in our cases 2 hypothesis:

a) immunoglobulins which carry light chains with uncomplete antigenic determinants and which are specific for the disease, are synthesized in multiple sclerosis and subacute sclerosing panencephalitis.

b) The antisera used are deficient in certain antibodies to the proteins studied.

3. The results we obtain for the serum are not entirely conclusive. The kappa/lambda ratio seems to depend on the state of the serum: frequent freezings and thawings, conservation at $4^{\circ} \mathrm{C}$, and even in a freezer, modify the ratio at random. Spontaneous proteolysis, due to the presence of plasmin in the serum, could occur and influence the light chain concentration. The kappa/lambda ratios we found in control serum are slightly superior to values reported in the literature. This may be due to the use of Bence Jones proteins as standards instead of the generally used standard serum. For the determination of free light chains one has to use Bence-Jones proteins as references, because the antisera used only react with free light chains; in order to remain in the same standard conditions, we also used the same Bence-Jones proteins for the assay of the total light chains.

\section{Conclusion}

In spite of the discussed technical aspects, we think we can assume that multiple sclerosis and subacute sclerosing panencephalitis synthetize immunoglobulins which are different for both diseases by their light chain quantitative distribution. The oligoclonal reaction of the gamma-globulins in multiple sclerosis-cerebrospinal fluid and in subacute sclerosing panencephalitis serum and cerebrospinal fluid, although non specific, is an important tool in the diagnostic approach of those diseases. To gain a better insight in their immunopathology, we thought that analysis of the constituents of the IgG's, could be of value. Some 
previous results showed that subacute sclerosing panencephalitis serum immunoglobulins do not differ by the sedimentation velocity coefficients of isolated IgG, $\mathrm{Fab}$ and $\mathrm{Fc}$ fragments from the control values. On the other hand kappa and lambda light chains of multiple sclerosis and subacute sclerosing panencephalitis immunoglobulins have a different quantitative distribution in serum as well as in cerebrospinal fluid.

\section{References}

1. Lowenthal, A. (1964), Agar gel electrophoresis in Neurology (Elsevier Publishing Company).

2. Link, H. \& Zetterwall, O. (1970) Clin. Exp. Immunol. 6, 435-438.

3. Iwashita, H., Grunwald, F. \& Bauer, H. (1974), J. Neurol. 207, 45-52.

4. Mancini, G. A., Carbonara, A. \& Heremans, J. (1965), Immunochemistry 2, 235-254.
From our results it can be stressed that the immunoglobulins of multiple sclerosis and subacute sclerosing panencephalitis have characteristic features: in multiple sclerosis kappa chains predominate, whereas lambda chains predominate in subacute sclerosing panencephalitis.
5. Madhosingh, C. \& Wood, J. M. (1971), Anal. Chem. 44, 523-527.

6. Lietże, A., Sịnclair, C. \& Rowe, H. (1970), Clin. Biochem. 3, $335-338$.

7. Mulder, J., Sloots, L. C. E. \& Verhaar, M. A. T. (1972), J. Immun. Methods $1,211-213$.

8. Mulder, J. \& Verhaar, M. A. T. (1973), Clin. Chim. Acta 45, $325-333$.
Lic. Sc. F. Bollengier B-1000 Brussels Eversstraat 2 